\title{
Classical Karst hydrodynamics: a shared aquifer within Italy and Slovenia
}

\author{
L. ZINI, C. CALLIGARIS \& E. ZAVAGNO \\ Dipartimento di Matematica e Geoscienze (D.M.G.) - Università degli Studi di Trieste, Italy \\ zini@units.it
}

\begin{abstract}
The classical Karst transboundary aquifer is a limestone plateau of $750 \mathrm{~km}^{2}$ that extends from Brkini hills in Slovenia to Isonzo River in Italy. For 20 years, and especially in the last two years, the Mathematic and Geosciences Department of Trieste University has run a monitoring project in order to better understand the groundwater hydrodynamics and the relation between the fracture and conduit systems. A total of 14 water points, including caves, springs and piezometers are monitored and temperature, water level and EC data are recorded. Two sectors are highlighted: the southeastern sector mainly influenced by the sinking of the Reka River, and a northwestern sector connected to the influent character of the Isonzo River. Water table fluctuations are significant, with risings of $>100 \mathrm{~m}$. During floods most of the circuits are under pressure, and only a comparative analysis of water levels, temperature and EC permits a precise evaluation of the water transit times in fractured and/or karstified volumes.
\end{abstract}

Key words Classical Karst; hydrogeology; transboundary aquifer

\section{INTRODUCTION}

The Classical Karst is a transboundary area shared between Italy and Slovenia of approx. $750 \mathrm{~km}^{2}$ that extends from southeast of the Isonzo River to Postumia town. It is characterized by a large variety of Karst landforms so that it has been considered one of the best examples of Karst in the world. In the common imagery, Timavo spring represents the forceful outflow of the hypogean waters present in the Classical Karst being fed not only by precipitation, but also by the Reka waters sinking in the impressive Škocjan sinkholes (UNESCO heritage since 1986). From a hydrogeological point of view, Timavo spring is one of the resurgence water points of a real complex karstified hydrostructure with an average thickness of at least 500-600 m, extending as a rectangular plateau for about $40 \mathrm{~km}$ in a SE-NW direction and $18 \mathrm{~km}$ in a SW-NE direction. The drainage basin of the Reka River covers an area of about $407 \mathrm{~km}^{2}$.

In the aquifer hydrodynamics, a relevant role is played by the allogenic inputs related to nonKarst sectors while feeding the underground waters. These flow at the bottom of the Karst hydrostructure where articulated pathways (more or less karstified) drain the waters from the spring's area into the Adriatic Sea.

Since 1995 the Department of Mathematics and Geosciences of Trieste University, installed an instrument network along the main flow paths to continuously monitor water levels, temperature and electrical conductivity. The monitored water points are located in the springs, in the caves and in several piezometers (Fig. 1). Data recorded and analysed permit a better understanding of the groundwater hydrodynamics, highlighting the contribution to the flow from the different parts of the hydrostructure and defining the relation between fracture and conduits through the study and the analysis of the hydrographs; this is the aim of the ongoing project.

\section{GEOLOGICAL AND HYDROGEOLOGICAL SETTINGS}

The Classical Karst area is a portion of the carbonatic piattaforma carsico-friulana, representing the extreme northeastern part of the Adria plate. It consists of a thick succession of carbonatic rocks of Triassic till Eocene age, overlapped by a clastic quartz-feldspar-limestone succession called Flysch (Zini et al. 2011). From a structural point of view, the Karst area is characterized by an asymmetric anticline having a NW-SE oriented axis, complicated by a series of folds and faults. Among the folds and faults, the most significant ones are parallel to the main structure, displacing its hillside and creating a small graben and horst.

The geostructural analysis (Cucchi et al. 2001) indicates that the geologic structural characteristics are the main controlling factors in the evolution of the Classical Karst: a discontinuity 


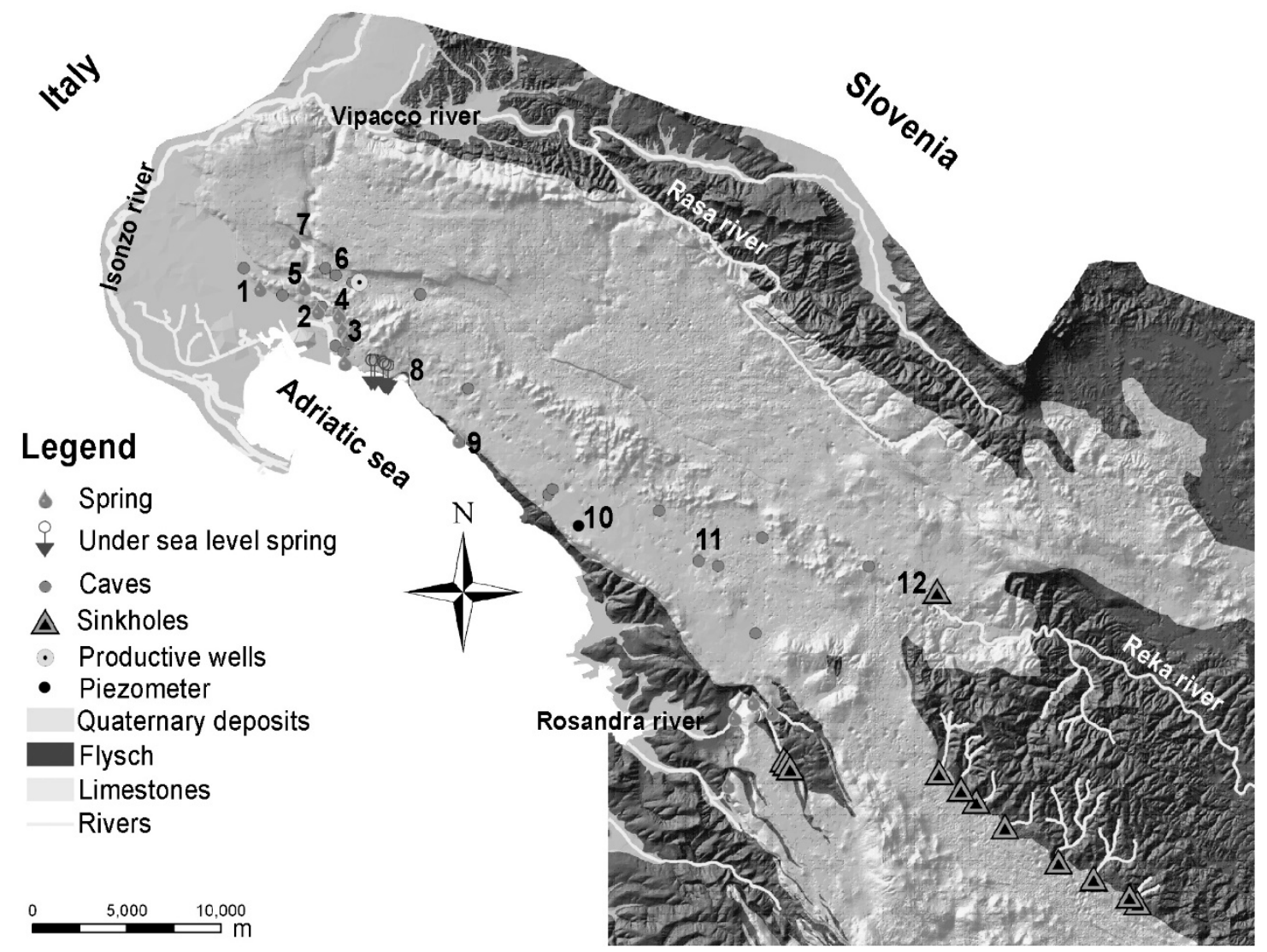

Fig. 1 Sketch of the study area. springs: 1 Monfalcone, 2 Lisert, 3 Timavo and Sardos, 4 Moschenizze, 5 Pietrarossa and Sablici, 7 Doberdò, 8 costal springs, 9 Aurisina. Caves: 6 Comarie, 11 Trebiciano, 12 Škocjan. 10 Opicina piezometer.

trend controlled by the Alpine and Dinaric stresses gave rise to a network of fractures from which the main conduits formed. The maximum dip strata and the main subvertical discontinuities are the preferential directions for galleries and shafts development. The caves still concerned by active flows (Škocjanske sinkhole, Trebiciano Abyss, Timavo spring), have flow directions in contrast with the regional one, which is mainly SE-NW oriented (Cucchi et al. 2000). Almost $33 \mathrm{~km}$, as a straight line, separate Škocjanske sinkhole from Timavo's springs. These are surely less than the flow path length reflecting the local structural conditioning.

Basically, Classical Karst is made up of two completely different lithotypes (limestones and Flysch) having distinct hydrogeological characteristics. The behaviour of the Reka-Timavo aquifer system reflects this situation, in fact, from a hydrogeological point of view, the aquifer recharge is due to three different contributions: the authogenic recharge resulting from the precipitations on the Karst surface; the allogenic one due to the sinking of the Reka River in the Skocjanške sinkhole and the input coming from the Isonzo alluvial aquifer (Fig. 1). In the Karst area, the first input is the average rainfall contribution considered between $1000 \mathrm{~mm} / \mathrm{year}$ in the coastal area and 2600 $\mathrm{mm} /$ year in the Reka hydrogeologic system, with an effective infiltration of $20.6 \mathrm{~m}^{3} / \mathrm{s}$ (Civita et al. 1995). The second input is from Reka River. From the springs' area, it flows for about $43 \mathrm{~km}$ on impermeable rocks in Flysch facies; for the last $7 \mathrm{~km}$, it flows on limestone lithotypes developing an influent character. After $50 \mathrm{~km}$ from the spring area, the Reka River totally sinks into the Škocjan sinkhole. It has a mutable discharge with values within the range of $305 \mathrm{~m}^{3} / \mathrm{s}$ (in the high water conditions) $-0.18 \mathrm{~m}^{3} / \mathrm{s}$ (in low water conditions) with an average value of $8.26 \mathrm{~m}^{3} / \mathrm{s}$ (Gabrovšek and Peric 2006). The third important water input is occurring in the northwestern sector, along a section of 5-6 km, in correspondence with the contact between limestones and the Isonzo alluvial aquifer. Its contribution, assumed since the beginning of last century (Timeus 1928), has been later estimated and verified using natural tracers (Mosetti and D'Ambrosi 1963, Gemiti and Licciardello 
1977, Cancian 1987, Doctor et al. 2000, Samez et al. 2005) and water hydrogeological balance computation, as $10 \mathrm{~m}^{3} / \mathrm{s}$ (Zini et al. 2013).

All the seeped waters are later drained by the spring system enclosed in a few square kilometres along the coast from Aurisina spring to Monfalcone town. The main spring is the Timavo, with an average discharge of $29.3 \mathrm{~m}^{3} / \mathrm{s}$, and the second is Sardos $\left(1.9 \mathrm{~m}^{3} / \mathrm{s}\right)$, and in third are all the other smaller springs as Aurisina $\left(0.3 \mathrm{~m}^{3} / \mathrm{s}\right)$, Moschenizze $\left(0.5 \mathrm{~m}^{3} / \mathrm{s}\right)$, Pietrarossa and Sablici lakes $(1.2$ $\left.\mathrm{m}^{3} / \mathrm{s}\right)$, Monfalcone $\left(0.2 \mathrm{~m}^{3} / \mathrm{s}\right)$, Lisert $\left(1.0 \mathrm{~m}^{3} / \mathrm{s}\right)($ Gemiti 1984,1995$)$, and lastly the coastal springs arising below sea level located between Aurisina and Timavo, having an average estimated discharge of $0.5-1 \mathrm{~m}^{3} / \mathrm{s}$.

The aquifer is also highly karstified at considerable depths: cave divers explored the conduits starting from Timavo spring reaching more than $80 \mathrm{~m}$ b.s.l.; well withdrawals linked to the Slovenian aqueduct network are realized at 55-70 m b.s.l., corresponding with Karst conduits (Urbanč et al. 2012) and finally at the eastern margin of the Classical Karst area, a well has been drilled and at about $180 \mathrm{~m}$ b.s.l. intercepting a cave where stalactite fragments, gravels and abundant freshwater venues were identified.

\section{The monitoring network}

The researchers of the Mathematic and Geosciences Department of Trieste University (DMG) have monitored the available water points on the Italian Classical Karst territories since 1995, jointly with Slovenian partners (Park Škocjanske Jame and KRI of Postojna) for the areas outside the Italian borders. Sharing information is the best way to better understand and protect the water resources and such a complex Karst hydrodynamic structure.

Instruments used in the monitoring network are Schlumberger Water Services CTD DIVER datalogger devices, recording continuously water levels (pressure sensor), temperature and EC (four electrode conductivity cell). The sample interval used in the studies is 30-60 minutes synchronized for all of them. Instruments installed in the Karst area have a broad coverage (Fig. 1) and the data recorded provide a huge help in understanding the water flow behaviour, particularly the monitored parameters which can be used in the identification of the carried out flow paths, as either conduits or a spread fractured network, and this can be done by analysing some examples.

Considering all the available data, three monitoring points are meaningful for understanding the behaviour of the underground water flow for a conduit structure: Škocjan sinkhole, Trebiciano Abyss (with the monitoring station positioned at $330 \mathrm{~m}$ of depth inside the cave) and Timavo spring (Fig. 2). For these points, almost 15 years of data have been recorded and analysed. As the transit times between Skocjan and Timavo spring are very short, underground waters maintain the characteristics (decreased amplitude) they had at the sinking moment at Skocjan sinkhole. Analysing the recorded parameters, only for the temperature, a seasonal behaviour is recognized with higher values during summertime and lower ones in January and February. Water levels and EC are not recognizable seasonality trends, but the effects of the flood events are clear from the sinking points to the spring area. During floods, sinking waters are generally characterized by a rapid increasing discharge (with an increasing water level) with a decrease in EC and T values. Only temperature deviates from this trend: especially in summertime, warm precipitations increase temperatures during floods. The same behaviour, very clear in the Škocjan sinkhole, is also recognized at the Trebiciano Abyss and Timavo spring, but with decreased amplitude. Data recorded at Timavo spring also highlight the influence of other contributions, which are especially meaningful at low water regime, while during floods only the Reka influence is recorded.

Therefore, the analysed data highlighted a highly effective drainage system with a general fast water replacement. Water table fluctuations are significant (Casagrande et al. 2005) and a comparative qualitative analysis of the water levels, temperature and EC permitted the evaluation of the water transit times (Galleani et al. 2011). During floods analysing the peak delay among Škocjan, Trebiciano and Timavo spring water transit times were evaluated to be $200-800 \mathrm{~m} / \mathrm{h}$ between Škocjan and Trebiciano and $150-500 \mathrm{~m} / \mathrm{h}$ between Trebiciano and Timavo spring, highlighting a prevailing circulation having a conduit character. 
The behaviour of the aquifer is different when leaving from the main conduits. Other monitoring points have been compared with Opicina piezometer and Trebiciano Abyss. Water table fluctuations are comparable, main peaks are almost coincident, but conductivity and temperature act in a completely different way. In Opicina's piezometer there are no recognisable temperature fluctuations, and EC is on average higher than Trebiciano Abyss. Rough decreasing in the EC values due to the neoinfiltration waters are not highlighted. In contrast, during the main floods, an EC increase is observed due to the piston flow effect. In this aquifer sector, high water levels usually record around $40 \mathrm{~m}$ on average, but increase up to $100 \mathrm{~m}$ during severe flood events (Fig. 3, Trebiciano Abyss).

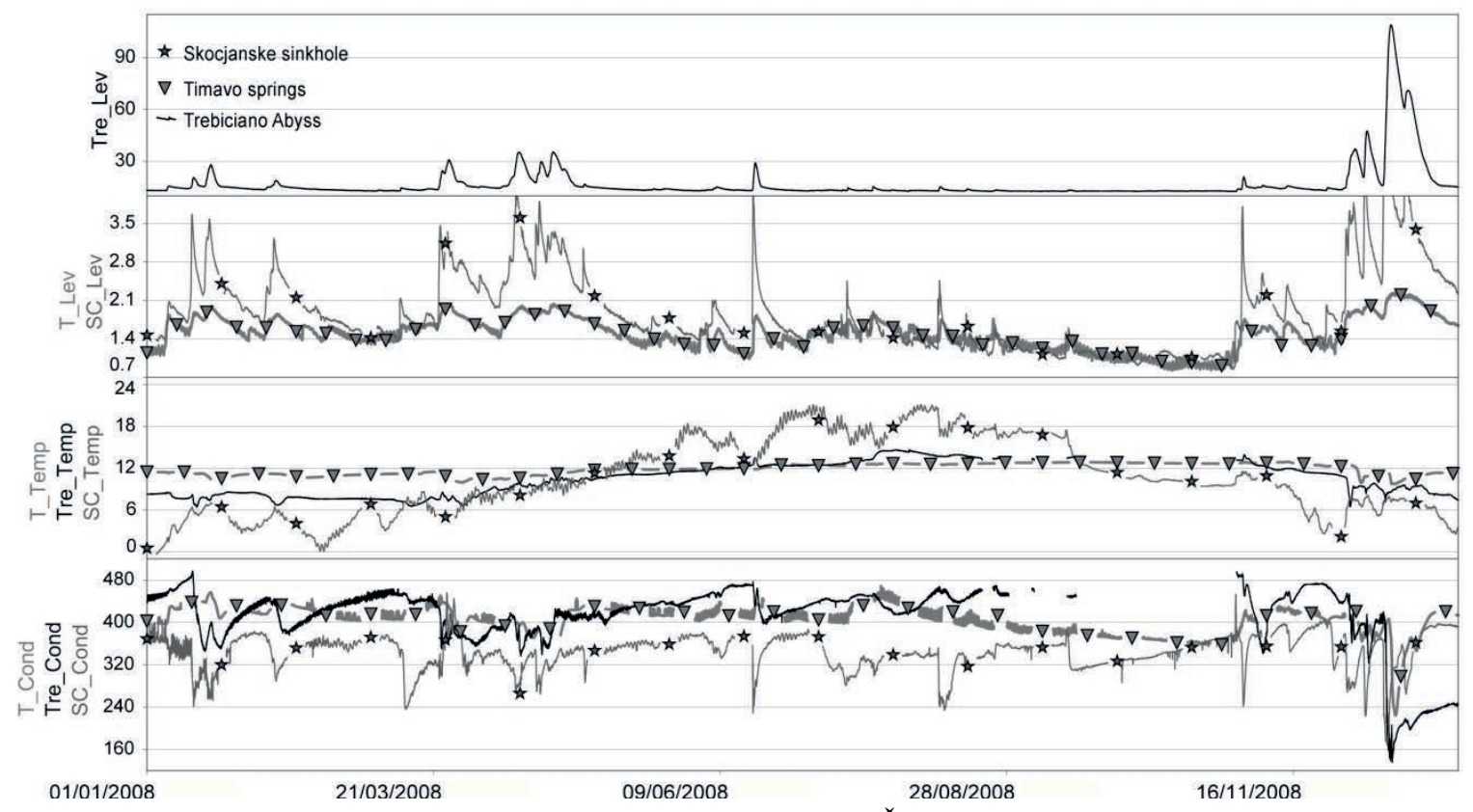

Fig. 2 Analysed data (year 2008: January-December) for the Škocjanske sinkhole, Trebiciano Abyss and Timavo spring. Represented parameters are water level (m a.s.l.), temperature $\left({ }^{\circ} \mathrm{C}\right)$ and $\mathrm{EC}(\mu \mathrm{S} / \mathrm{cm})$.

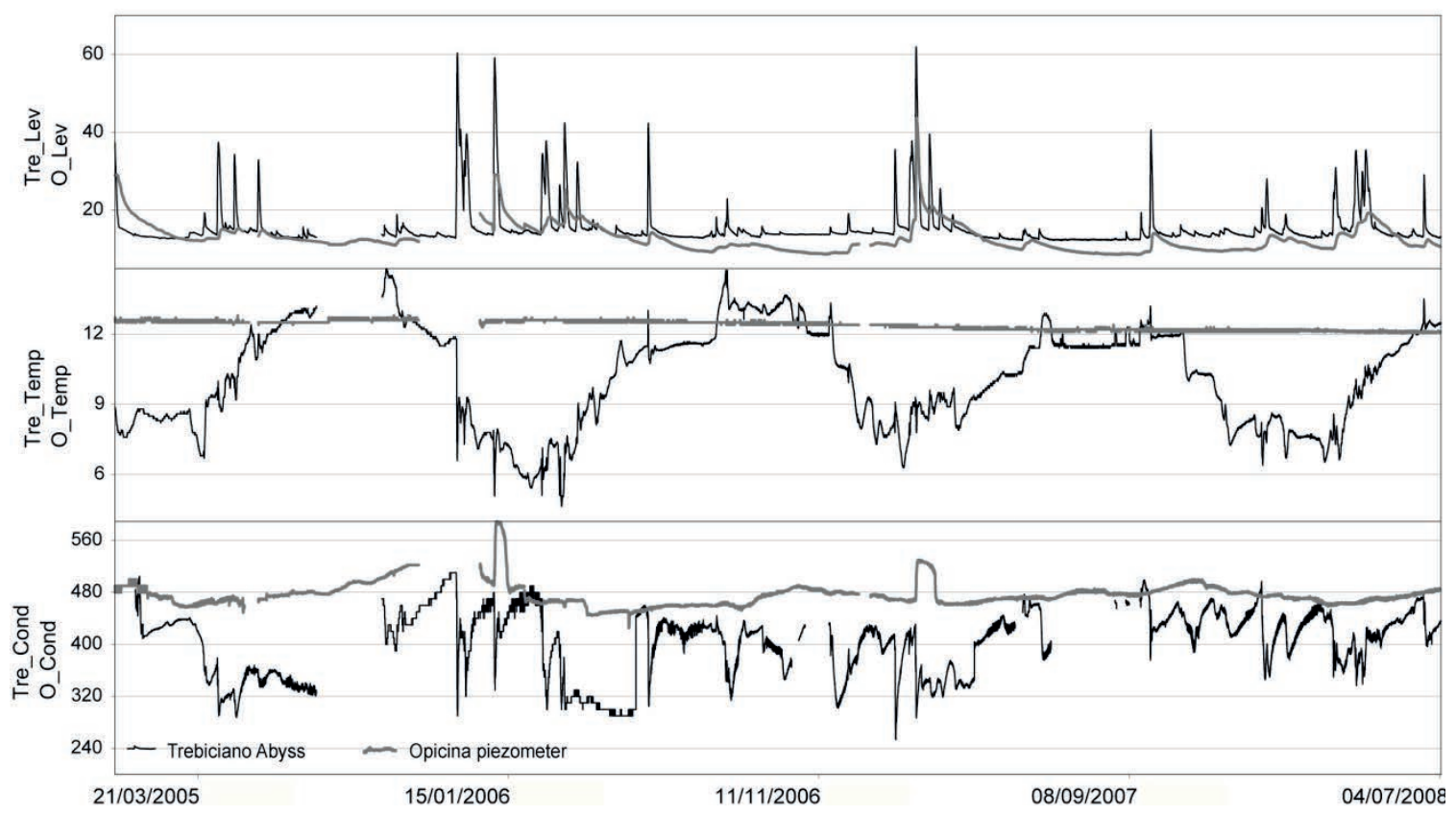

Fig. 3 Three years, 2005-2008, of automatic measures in Trebiciano Abyss and Opicina piezometer. 


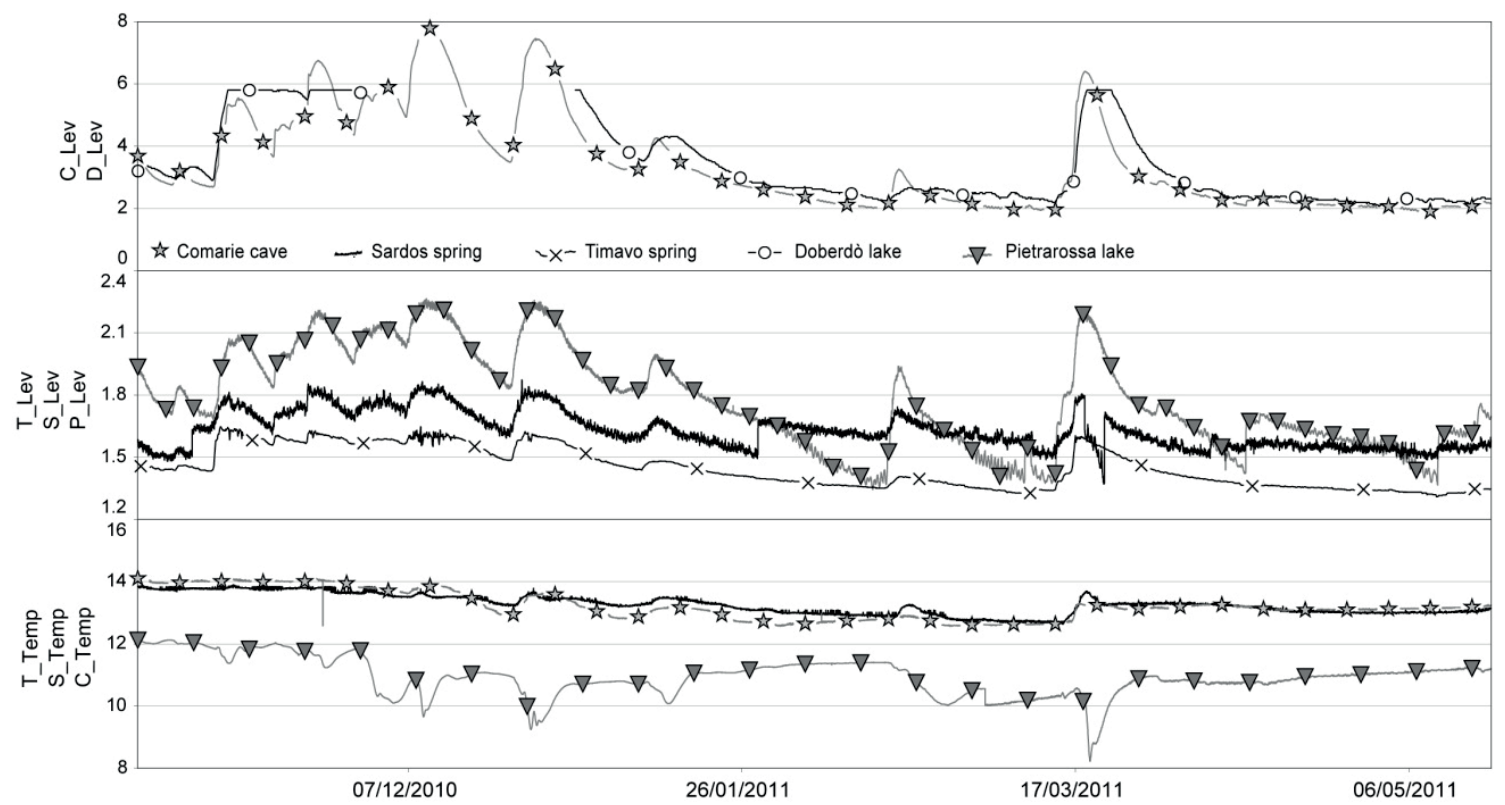

Fig. 4 Water level and temperature parameters recorded (2010-2011) for the Comarie Cave, Sardos and Timavo springs, Doberdò and Pietrarossa lakes.

Moving towards the northwestern side of the Karstic hydrostructure, the groundwater flow behaviour is quite different. A series of monitoring points (Comarie cave, Sardos and Timavo spring, as well as Doberdò lake), recording water levels and temperature, located in caves, lakes and springs were analysed (Fig. 4). Water levels are totally comparable, while temperature data indicates different effects. Comarie cave and Sardos springs (about $200 \mathrm{~m}$ away from Timavo spring) present a similar behaviour: small positive changes in temperature are linked to a rising water level showing a moderate so-called piston effect due to pushing freshly infiltrated waters and mobilizing resident groundwaters. This makes a moderately effective drainage system.

Despite the lack of EC data, for Timavo's spring monitoring point, an increasing water level is observed, which corresponds to a decrease in temperature values due to a highly effective drainage system.

For Doberdò and Pietrarossa lakes, small water level fluctuations in the low water period are hardly linked to hydrometric fluctuations of the Isonzo River caused by its Slovenian regulation (Samez et al., 2005). This demonstrates the direct influence of the Isonzo River on the lakes water regime.

Summarizing, the saturated zone, or the piezometric surface in low or normal water regime, is positioned at about $2-5 \mathrm{~m}$ a.s.l. in the spring area of Ronchi dei Legionari - Jamiano - Sistiana, while it is about $15 \mathrm{~m}$ a.s.1. in the central area of Prosecco - Opicina - Fernetti. In the NW sector, during normal floods, the thickness of the oscillating zone is about 3-4 m, while during exceptional ones it increases up to $10 \mathrm{~m}$. The surface is obviously discontinuous. There are several dry zones where discontinuities are not open and persistent enough to allow the water flow. Inhomogeneity is indeed remarkable, the network hierarchization and dimension are randomly distributed and only partially guided by the geological and geostructural characteristics (Cucchi et al. 2000).

\section{CONCLUSIONS}

The Classical Karst has been evolving for at least 10 million years, its underground network is highly developed and complex. In this framework, it is possible to distinguish two main sectors: the southeastern one between Škocjan sinkhole and Timavo spring, and the northwestern one where water flows through the Isonzo alluvial plain towards Karst hydrostructure up to Timavo spring. The first sector is characterized by the sinking waters of Škocjan sinkhole and by high gradients. It represents the so-called underground Timavo system where large conduits quickly transfer Reka 
waters directly into the spring area. The northwestern sector (Isonzo system) is instead characterized by lower gradients in a Karst fractured system spreaded along the edge of the plain. In addition to the two allogenic inputs, it is necessary to add also the contribution due to the effective precipitation on both sectors. The two sectors are anyway draining waters from the hydrostructure and this is apparent along all the coastal springs. From Aurisina to Timavo, springs are strongly connected to the Timavo system, while for the western ones, such as Moschenizze, Lisert and Sablici, there is an involvement of a northwestern hydrodynamic system. The linking point between the two systems are the Sardos and Timavo springs. During low water regime, both springs are draining waters, mainly coming from the Isonzo system. Instead, in high water regime, water drained is coming from the Timavo system: Timavo spring is only draining Timavo waters, while Sardos spring is draining mixed waters (from Timavo and Isonzo systems). During normal flow, Timavo spring is draining mainly Timavo waters and Sardos spring is draining only Isonzo waters. In conclusion, the methodology used permits the broad characterization of the groundwater flow dynamics in the Karst hydrostructure, highlighting the differences between fracture and conduit systems.

\section{REFERENCES}

Cancian, G. (1987) L'idrologia del Carso goriziano-triestino tra l'Isonzo e le risorgive del Timavo. Studi Trentini di Scienze Naturali 64, 77-98.

Casagrande, G., Cucchi, F. and Zini, L. (2005) Hazard connected to railway tunnel construction in Karstic area: applied geomorphological and hydrogeological surveys. Natural Hazards and Earth System Sciences 5, $243-250$.

Civita, M., et al. (1995) The Timavo hydrogeologic system: an important reservoir of supplementary water resources to be reclaimed and protected. Acta Carsologica 24, 169-186.

Cucchi, F., et al. (2001) Influence of geostructural conditions on the speleogenesis of the Trieste Karst (Italy). Geologica Belgica $4(3-4), 241-250$.

Cucchi, F., et al. (2000) Recent developments in knowledge of the hydrogeology of the "Classical Karst". Acta Carsologica 29(14), 55-78.

Doctor, H.D., Lojen, S., and Hrovat, M. (2000) A stable isotope investigation of the classical Karst aquifer: evaluating Karst groundwater components for water quality preservation. Acta Carsologica 29(1), 79-92.

Gabrovšek, F. and Peric, B. (2006) Monitoring the flood pulses in the epiphreatic zone of Karst aquifer: the case of Reka River system, Karst plateau, SW Slovenia. Acta Carsologica 35(1), 35-45.

Galleani, L., et al. (2011) Validation of a Vulnerability Estimator for spring Protection Areas: The VESPA index. Journal of Hydrology 396, 233-245.

Gemiti, F. (1984) La portata del Timavo alle risorgive di S. Giovanni di Duino. Annali Gruppo Grotte Ass. XXX Ott. $7,23-41$.

Gemiti, F. (1995) Portata liquida e portata solida del Timavo alle risorgive di S. Giovanni di Duino. Hydrores 13, 75-88.

Gemiti, F. and Licciardello, M. (1977) Indagini sui rapporti di alimentazione delle acque del Carso triestino e goriziano mediante l'utilizzo di alcuni traccianti naturali. Annali Gruppo Grotte Ass 30 Ott. 6, 43-61.

Mosetti, F. and D'Ambrosi, C. (1963) Alcune ricerche preliminari in merito a supposti legami di alimentazione fra il Timavo e l'Isonzo. Boll Geograf Teor Appl 5(17), 69-84.

Timeus, G. (1928) Nei misteri del mondo sotterraneo: risultati delle ricerche idrogeologiche sul Timavo 1895-1914, $1918-1927$. Atti e Memorie Commissione Grotte “E. Boegan”'22, 117-133.

Samez, D., et al. (2005) Idrodinamica dei laghi di Doberdò e di Pietrarossa (Carso Classico, Italia). relazioni con le piene dei fiumi Isonzo, Vipacco e Timavo. Atti e Mem. Comm. Grotte "E. Boegan" 40, 13-152.

Urbanč, J., Mezga, K. and Zini, L. (2012) An assessment of capacity of Brestovica - Klariči Karst water supply (Slovenia). Acta Carsologica 41/1, 89-100.

Zini, L., et al. (2011) Potential impact of a proposed railway tunnel on the Karst environment: the example of Rosandra Valley, Classical Karst Region, Italy-Slovenia. Acta Carsologica 40/1, 207-218.

Zini, L., et al. (2013) Groundwater sustainability in the Friuli Plain. AQUA mundi 4, 41-54. 